UCRL-CR- -107988

DE91 017074

MUU \& จ I0J1

\title{
L TO H MODE TRANSITIONS AND ASSOCIATED PHENOMENA IN DIVERTOR TOKAMAKS
}

\author{
Dr. A. Punjabi
}

Hampton University

September 1990

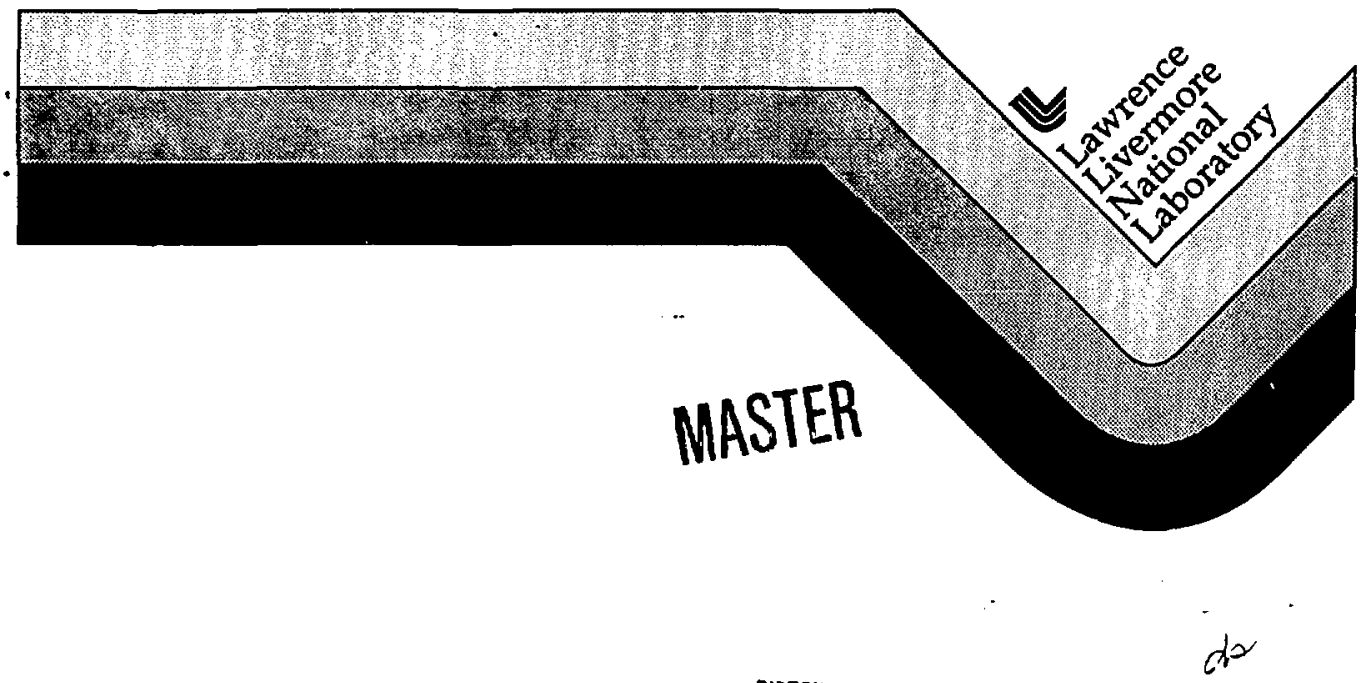




\section{DISCLAIMER}

Work eerformed ender the ausplees of the U.S. Depart. ment of Ewergy by Lamreace Llvermore National Labonlery under contract muber W-7405-ENG-48.

This doctimeat was wepuret es an account of work sponsored by an agency of the United States Government. Neither the United Stales Government mor the University of Californle nor any of their employees, makes any rarranty. express or implied, or assumes any venal liability or retpon. sibility for the eccuracy; completeness, or usefulaess of any information, apsuratus, produch, or process disclosed, or represents that its wo woutd not infringe privately ommed rights. Refereace herein to any specific commercial prodwets, process of service by trude anme, trademark maunfas turet, or othernise, does not wecessarily constitute or inply its eadorsement, rerommendation, or favoriag by the Linited States Government or the University of Californian. The views and opinions of authors expressed herein do not mecessarit) state or reflect chose of (he Unied States Governmente or the University of California, and shall not be esed for adrertisiog of product endorsement purposes. 
FINAL REPORT FOR THE FISCAL YEAR 1990 PROJECT TITLE: L to H Mode Transitions and Associated
Phenomena in Divertor Tokamaks

PRINCIPAL INVESTIGATOR: Dr. Alkesh Punjabi

INSTITUTION: Hampton University

Hampton, VA 23668

September 1990 
This is the final report for the research project titled "I to $H$ Mode Transitions and Associated Phenomena in Divertor Tokamaks ". The period covered by this report 13 the fiscal year 1990. This project is funded by lawrence Livermore National Laboratory under the HBCU Program of DOE. This report covers four aspects of the work done during this period. Each one is described in detall in the following:

\section{I_Publication:}

Durlng this period the PI published one paper in the international referred fournal. The paper is:

A Catastrophe Theory Study of a Two Chamber Model for a Tokamak Scrape-off and D1vertor

Alkesh Punjab1

Journal of Plasma Physics, vol, 42, 1989, p 59-74.

The reprint of this paper is attached with this report.

\section{Contributed Papers:}

One contributed paper was presented at the American Physical Soclety Division of Plasma Physics 1989 Annual Meeting on the research done in this profect. Detalls are;

Catastrophe Theory Study of Advanced Two Chamber Model Maria Lam and Alkesh Punjabl

Bull. Am. Phys. Soc., 34, 2137 (1989)

7. copy of the abstract of this paper is also attached with this report.

\section{Research Seminars:}

The PI presented one seminar at the Research in Physics at Hampton University, Department of Physics on September 2l, 1990. The part of this research seminar given by the $P I$ included the research done in this profect. Details are:

Catastrophes and Blfurcations in Toroldal Plasmas

Alkesh Punjabi

Research in Physics at $\mathrm{HU}$

Dept. of Physics Seminars

Sept. 21, 1990

Iy Development of Adyanced Two Chamber Model:

The theoretical work on the development of advanced two chamber model for plasma transport in the main plasma and divertor scrape-off region is now complete. This advanced model includes the effects of charge exchange and radiative 
loss processes. We have also developed a computer code to solve the equations of this model. At present, we are testing and debugging this code. A brief discussion of this advanced model is given below.

The advanced two chamber model equations are:

$$
\begin{aligned}
& \frac{d}{d s}(n u)=s \\
& \left.\frac{d}{d s}\left(m n u^{2}+p\right)=-m n n_{0}<\sigma v\right\rangle_{c x}\left(u+v_{0}\right) \\
& \frac{d}{d s}\left[q^{*}+\left(5 n T+\frac{1}{2} m n u^{2}, u\right]=w_{\text {lon }}+w_{c x}+w_{\text {rad }}\right.
\end{aligned}
$$

Here the new terms for charge exchange and radiative losses are included in the two chamber model equations. These terms in energy transport equation are given by

$$
w_{c x}=-\left(\frac{3}{2} T-E_{0}\right) n n_{0}\langle o v\rangle_{c x}
$$

and

$$
\omega_{r a d}=-n^{2} Q
$$

$Q$ is the radiation power parameter. For the neutral transport, we use the Post model:

$$
\frac{d}{d s}\left(n_{0} v_{0}\right)=-s
$$

The Integration of equations (1) - (3) with the help of equation (6) will yield:

$$
b_{1} T_{1}^{4}+b_{3} T_{1}^{3}+b_{2} T_{1}^{2}+b_{1} T+b_{0}=0
$$

where

$$
b_{1}=b_{1}\left(x, y, n_{0}, f_{p u m p}\right)
$$

Here $x$ and $y$ are defined as

$$
x=\frac{n_{2}}{n_{1}}
$$

and 


$$
y=\frac{T_{2}}{T_{1}}
$$

Thus with given values of $x, y, n_{0}$ and $f_{\text {pump }}$, one can solve the quartic equation and then solve for the recycling parameter $R$ and the heat $f$ lux $Q_{1}$ from main plasma scrape-off to the divertor.

Catastrophe Theory Study:

The above analysis can be performed in the set-up of catastrophe theory by considering the parameters $C=\left(R, Q_{1}\right)$ as control vector and the variables $x=\left(n_{2}, n_{1}, T_{1}, T_{2}\right)$ as the state or behavior vector. Then behavior of $X$ as a function of c will yield the equilibrium surfaces. A study of these surfaces can yield catastrophic behavior of the system.

\section{References:}

1. Punjabi A., J. Plasma Phys., 42, p 59-74 (1989)

2. Punjabi A., Phys. Lett. A, 133, p 315-318 (1988)

3. Punjabi A. and Vahala G., J. Plasma Phys., 33, p 119-149 (1985)

4. Punjabi A. and Vahala G., Phys. Lett. A, 101, p 331-334 (1984)

5. Punjabl A. and Vahala G., J. Plasma Phys., 30, p 389-421 (1983)

6. Vahala G., Punjabi A. and Harris E. G., Phys. Rev. Lett., 48, p 680-683 (1982) 